November 2007

\title{
Ordinariness and Orders: Explaining Popular Participation in the Rwandan Genocide
}

Lars Waldorf

Follow this and additional works at: https://digitalcommons.usf.edu/gsp

\section{Recommended Citation}

Waldorf, Lars (2007) "Ordinariness and Orders: Explaining Popular Participation in the Rwandan Genocide," Genocide Studies and Prevention: An International Journal: Vol. 2: Iss. 3: Article 8.

Available at: https://digitalcommons.usf.edu/gsp/vol2/iss3/8

This Articles is brought to you for free and open access by the Open Access Journals at Digital Commons @ University of South Florida. It has been accepted for inclusion in Genocide Studies and Prevention: An International Journal by an authorized editor of Digital Commons @ University of South Florida. For more information, please contact digitalcommons@usf.edu. 


\title{
Ordinariness and Orders: Explaining Popular Participation in the Rwandan Genocide
}

\author{
Lars Waldorf \\ Centre for International Human Rights, Institute of \\ Commonwealth Studies, University of London
}

The most troubling and perplexing aspect of the Rwandan Genocide is why so many joined the killings so quickly. This participation seems even less comprehensible given the violence's terrifying intimacy: ordinary killers often turned on their Tutsi neighbors and family members, using machetes and other everyday tools. Searching for answers, journalists and even some scholars have clutched at comforting metaphors and mono-causal explanations: a "blood orgy," tribalism, ethnic hatred, hate radio, a "culture of obedience," structural violence, and "conspiracy to murder." With bracing clarity and scrupulous fairness, Scott Straus painstakingly demolishes these simplistic notions and sets a new standard for empirical research on mass violence in The Order of Genocide.

Using data from interviews with 210 convicted, confessed perpetrators and with a range of actors in five communities, Straus constructs a sophisticated explanation of how genocidal violence happened at the local level. First, he finds that most perpetrators in rural Rwanda were ordinary farmers (though rural elites and young thugs played a crucial role in driving the violence). Second, most of those ordinary perpetrators committed genocide for fairly banal reasons: "the Rwandans' motivations were considerably more ordinary and routine than the extraordinary crimes they helped commit" (96). Third, he calculates that between 175,000 and 210,000 civilians participated in genocidal violence-an enormous number, to be sure, but far fewer than the half-million who now stand accused in Rwanda's community courts (gacaca). Finally, he identifies three key factors behind the widespread participation: (1) anger, fear, and uncertainty caused by the renewed civil war; (2) opportunism linked to local power struggles; and (3) social pressure and coercion derived from intra-group dynamics, state authority, communal labor obligations, and social surveillance. The latter point is perhaps Straus's most controversial finding. Challenging popular conceptions of the Rwandan Genocide, he writes that "intra-ethnic coercion and pressure [among Hutu] appear to have been greater determinants of genocidal participation than interethnic enmity [between Hutu and Tutsi]" (148). This explanation is consistent with many of the testimonies I have heard in gacaca trials, but more systematic analyses of those testimonies and more micro-level studies are needed.

A constant refrain that Straus hears from confessed perpetrators is that they were following orders and that disobedience would have led to punishment or even death. This sounds like egregious self-absolution from admitted killers, but Straus makes us take it-and them-seriously. Nonetheless, it would have been helpful to parse perpetrators' motivations more closely to distinguish better among group conformity

Lars Waldorf, "Ordinariness and Orders: Explaining Popular Participation in the Rwandan Genocide," Genocide Studies and Prevention 2, 3 (November 2007): 267-270. (C) 2007 Genocide Studies and Prevention. doi: 10.3138/gsp.2.3.267 
(peer pressure), obedience to authority, and coercion or duress. These distinctions matter enormously for imputing legal guilt, assigning moral blame, and understanding why ordinary men kill. In his classic study of German police reservists in Nazi-occupied Poland, Christopher Browning emphasizes the need to distinguish obedience from conformity, particularly as perpetrators are more likely to invoke authority to diminish (or erase) their personal responsibility. ${ }^{1}$

In explaining obedience, Straus is right to emphasize the historical continuity of Rwanda's strong administrative state and compulsory labor mobilizations. Yet it is also important to recall Rwanda's long (if less well known) tradition of peasant disobedience. In the 1980s, for example, peasants uprooted state-owned coffee bushes as the world price of coffee fell, and they often shirked mandatory communal labor (umuganda). Even those who participated in the genocide sometimes resisted government orders to bury the rotting corpses. More recently, the current regime has had difficulty in compelling people to participate in gacaca trials. I once saw farmers running into banana groves to avoid local officials who were rounding up community members to attend gacaca. All this suggests that ordinary Rwandans have a great deal of agency: they choose to conform or obey when it best suits their self-interest.

Straus runs into a major explanatory difficulty with his emphasis on social pressure and coercion. Having estimated a high of 210,000 perpetrators, he is forced to recognize a problem: "If my hypothesis is correct that... social pressure and coercion played an important role, then why were there not more genocide perpetrators?" (120). He offers three possibilities: first, some of those approached were able to get out of killing (by paying a fine or feigning illness); second, the mobilization of perpetrators was random (and thus partly a matter of luck); third, most of the killing was finished before more people could be mobilized. As Straus recognizes, further research is needed to answer the crucial question of why some became perpetrators and some did not. Just as importantly, we need to understand the motivations of, and pressures on, ordinary bystanders and ordinary rescuers. Did they perceive the level of social pressure and coercion differently, and, if so, why?

There are several limitations to Straus's study, which he is the first to acknowledge. I want to note just three here. First, most of his informants were fairly low-level perpetrators, so it is not surprising that they offer a defense of "following orders." Perhaps as more members of the rural elites and the genocidal government confess in order to win reduced sentences, there will be opportunities to investigate their motivations and decision making. It will be particularly interesting to see whether they corroborate the statements of those ordinary killers who claim to have been unwilling executioners. Second, most Rwandan perpetrators (even those already convicted) have incentives to minimize their role, rationalize their actions, and shift the blame to others. This process is often linked to an economy of guilt within Rwanda's prisons, where prisoners buy and sell confessions, inculpations, and exculpations. In addition, prisoners are acutely aware of how their confessions (especially the naming of accomplices) will affect their families on the outside, setting them up as possible targets for revenge.

Finally, Rwandans are highly practiced at what one political scientist elsewhere has termed "ritualized dissimulation." 2 When 91\% of his respondents tell him they have never disobeyed authorities, Straus reacts with appropriate skepticism, while also recognizing how important it is for them to be perceived as complying with authority. Yet this makes it all the more necessary to measure perpetrators' narratives 
in terms of compliance with the current regime's ideological discourse. Indeed, his respondents' accounts are consistent with the government's emphasis on explaining the genocide in terms of "bad leadership" and an uneducated peasantry inculcated in habits of obedience. Straus's interviewees may also have minimized ethnic tensions before the genocide, in conformity with the current regime's suppression of ethnicity.

Overall, Straus's book takes it place besides Jan Gross's Neighbors ${ }^{3}$ and Christopher Browning's Ordinary Men as essential reading for anyone wanting to understand how ordinary men can so quickly become génocidaires. Such understanding is essential to preventing genocide. For, as Rwanda reminds us, mass violence is impossible without widespread civilian participation, cooperation, and passivity.

\section{Notes}

1. Christopher R. Browning, Ordinary Men: Reserve Police Battalion 101 and the Final Solution in Poland (New York: Penguin, 2001), 174.

2. Lisa Wedeen, Ambiguities of Domination: Politics, Rhetoric, and Symbols in Contemporary Syria (Chicago: University of Chicago Press, 1999), 82.

3. Jan T. Gross, Neighbors: The Destruction of the Jewish Community of Jedwabne, Poland (Princeton, NJ: Princeton University Press, 2001). 